\title{
Diminution of Oxalate Induced Renal Tubular Epithelial Cell Injury and Inhibition of Calcium Oxalate Crystallization in vitro by Aqueous Extract of Tribulus terrestris
}

\author{
A. Aggarwal, S. Tandon, S. K. Singla, C. Tandon \\ Department of Biotechnology and Bioinformatics (AA, ST, CT), Jaypee University of Information \\ Technology, Waknaghat, Solan, India and Department of Biochemistry (SKS), Panjab University, \\ Chandigarh, India
}

\begin{abstract}
Purpose: Recurrence and persistent side effects of present day treatment for urolithiasis restrict their use, so an alternate solution, using phytotherapy is being sought. The present study attempted to evaluate the antilithiatic properties of Tribulus terrestris commonly called as "gokhru" which is often used in ayurveda to treat various urinary diseases including urolithiasis.

Materials and Methods: The activity of Tribulus terrestris was investigated on nucleation and the growth of the calcium oxalate $(\mathrm{CaOx})$ crystals as well as on oxalate induced cell injury of NRK 52E renal epithelial cells.

Results: Tribulus terrestris extract exhibited a concentration dependent inhibition of nucleation and the growth of CaOx crystals. When NRK-52E cells were injured by exposure to oxalate for $72 \mathrm{~h}$, Tribulus terrestris extract prevented the injury in a dose-dependent manner. On treatment with the different concentrations of the plant, the cell viability increased and lactate dehydrogenase release decreased in a concentration dependent manner.

Conclusion: The current data suggests that Tribulus terrestris extract not only has a potential to inhibit nucleation and the growth of the $\mathrm{CaOx}$ crystals but also has a cytoprotective role. Our results indicate that it could be a potential candidate for phytotherapy against urolithiasis.
\end{abstract}

Key words: phytotherapy; urolithiasis; calcium oxalate; NRK 52E, Tribulus terrestris

Int Braz, J Urol. 2010; 36: 480-9

\section{INTRODUCTION}

Nephrolithiasis is common, affecting up to $10 \%$ of the population at some point during their lifetime (1). Calcium-containing stones are the most commonly occurring to an extent of $75-90 \%$ followed by magnesium ammonium phosphate (Struvite) to an extent of $10-15 \%$, uric acid $3-10 \%$ and cystine $0.5-1 \%$ (2). Calcium oxalate stones are found in two different varieties, calcium oxalate monohydrate $(\mathrm{COM})$ or Whewellite, and calcium oxalate dihydrate (COD) or Weddellite. COM, the thermodynamically most stable form, is observed more frequently in clinical stones than COD and it has a greater affinity for renal tubular cells, thus responsible for the formation of stones in the kidney (3).

Various authors have suggested the role of crystal induced cell injury in the development of 
kidney stones by providing the sites for crystal attachment and retention within the kidneys $(4,5)$.

Oxalate, a metabolic end product and a major constituent of the majority of renal stones, has been shown to be toxic to renal epithelial cells of cortical origin (6). It has been observed that exposure of renal epithelial cells to oxalate which is a constituent of most kidney stones leads to a disruption of the normal activities of the renal epithelial cells such as altered membrane surface properties and cellular lipids, changes in gene expression, disruption of mitochondrial function, formation of reactive oxygen species and decreased cell viability (7).

Various mechanisms have been proposed to explain crystal retention (8). As a result of crystal growth and agglomeration, particles may be formed that are too large to freely pass the renal tubules. Alternatively, relatively small crystals could be retained by adhering to the surface of the urothelial lining and then increase in size (8).

The surgical methods available to treat kidney stones like extracorporeal shock wave lithotripsy have serious side effects. Therefore, it is worthwhile to look for an alternative for the management of urolithiasis. Many medicinal plants have been employed during ages to treat urinary stones though the rationale behind their use is not well established through systematic and pharmacological studies, except for some composite herbal drugs and plants (9-12). Plant medicines are in great demand both in the developed as well as developing countries for primary health care because of their wide range of biological and medicinal activities, higher safety margin and low cost.

Fruits of Tribulus terrestris (Zygophyllaceae) locally named as "gokhru" in India are commonly used in folklore to treat urolithiasis. So far, its diuretic properties have been documented in literature and it is actively used in various drug formulations of kidney stone treatments.

The present study aimed at investigating the efficacy of Tribulus terrestris on calcium oxalate crystal nucleation and growth in vitro as well as further examining the potency of Tribulus terrestris on oxalate induced injury in NRK 52E (rat renal tubular epithelial) cells.

\section{MATERIALS AND METHODS}

\section{Preparation of the Tribulus terrestris Extract}

The dried and matured fruits of Tribulus terrestris were obtained from "Natural Remedies Pvt. Ltd." at Bangalore in India. A collection of voucher specimens is available at the company.

The air-dried fine powdered plant fruits were boiled in distilled water. The extract was then filtered using Whatman No. 1 filter paper and the filtrate was evaporated in vacuum and dried using a rotary evaporator at $60^{\circ} \mathrm{C}(13)$. The final dried samples were stored in labeled sterile bottles and kept at $-20^{\circ} \mathrm{C}$. The various concentrations of the plant sample tested for their inhibitory potency were $25 \mu \mathrm{g} / \mathrm{mL}, 50 \mu \mathrm{g} / \mathrm{mL}$, $100 \mu \mathrm{g} / \mathrm{mL}, 200 \mu \mathrm{g} / \mathrm{mL}, 400 \mu \mathrm{g} / \mathrm{mL}$ and $1000 \mu \mathrm{g} / \mathrm{mL}$, which were prepared at the time of experiment and were referred to as aqueous extract of Tribulus terrestris.

For cell culture studies a stock solution of the dried aqueous Tribulus terrestris extract was dissolved in dimethyl sulfoxide (DMSO) [final concentration of the DMSO in the highest concentration of plant extract tested did not exceed $0.4 \%(\mathrm{v} / \mathrm{v})$ and did not affect the cell proliferation]. Further dilutions of the stock were done using serum free DMEM (Dulbecco's Modified Eagle's Media) and filtered by $0.3 \mathrm{~mm}$ syringe filter (14).

\section{Nucleation Assay}

The method used was similar to that described by Hennequin et al. with some minor modifications (15). Solutions of calcium chloride and sodium oxalate were prepared at the final concentration of 3 $\mathrm{mmoL} / \mathrm{L}$ and $0.5 \mathrm{mmoL} / \mathrm{L}$, respectively, in a buffer containing Tris $0.05 \mathrm{moL} / \mathrm{L}$ and $\mathrm{NaCl} 0.15 \mathrm{moL} / \mathrm{L}$ at $\mathrm{pH}$ 6.5. Both solutions were filtered through a $0.22 \mu \mathrm{m}$ filter; $33 \mathrm{~mL}$ of calcium chloride solution was mixed with $3.3 \mathrm{~mL}$ of the aqueous extract at different concentrations. Crystallization was started by adding 33 $\mathrm{mL}$ of sodium oxalate solution. The final solution was magnetically stirred at $800 \mathrm{rpm}$ using a PTFE-coated 
stirring bar. The temperature was maintained at $37 \mathrm{o}$ $\mathrm{C}$. The absorbance of the solution was monitored at $620 \mathrm{~nm}$ after every $1 \mathrm{~min}$. The percentage inhibition produced by the herb extract was calculated as [1(Tsi/Tsc)] X 100, where Tsc was the turbidity slope of the control and Tsi the turbidity slope in the presence of the inhibitor.

\section{Growth Assay}

Inhibitory activity against $\mathrm{CaOx}$ crystal growth was measured using the seeded, solution-depletion assay described previously by Nakagawa and colleagues (16). Briefly, an aqueous solution of $10 \mathrm{mM}$ Tris- $\mathrm{HCl}$ containing $90 \mathrm{mM} \mathrm{NaCI}$ was adjusted to $\mathrm{pH} 7.2$ with 4 $\mathrm{N} \mathrm{HC}$. Stone slurry $(1.5 \mathrm{mg} / \mathrm{mL})$ was prepared in 50 $\mathrm{mM}$ sodium acetate buffer ( $\mathrm{pH}$ 5.7). CaOx monohydrate crystal seed was added to a solution containing 1 $\mathrm{mM} \mathrm{CaCl} 2$ and $1 \mathrm{mM}$ sodium oxalate $(\mathrm{Na} 2 \mathrm{C} 2 \mathrm{O} 4)$. The reaction of $\mathrm{CaCl} 2$ and $\mathrm{Na} 2 \mathrm{C} 2 \mathrm{O} 4$ with crystal seed led to deposition of $\mathrm{CaOx}(\mathrm{CaC} 2 \mathrm{O} 4)$ on the crystal surfaces, thereby decreasing free oxalate that is detectable by spectrophotometry at $\lambda 214 \mathrm{~nm}$. When aqueous extract is added into this solution, depletion of free oxalate ions will decrease if the test sample inhibits $\mathrm{CaOx}$ crystal growth. Rate of reduction of free oxalate was calculated using the baseline value and the value after 30 -second incubation with or without test sample. The relative inhibitory activity was calculated as follows: $\%$ Relative inhibitory activity $=[(\mathrm{C}-\mathrm{S}) / \mathrm{C}] \times 100$, where $\mathrm{C}$ is the rate of reduction of free oxalate without any test sample and $\mathrm{S}$ is the rate of reduction of free oxalate with a test sample.

\section{Cell Culture}

Normal rat epithelial derived renal tubular epithelial (NRK 52E) cells were obtained from National Centre of Cell Sciences (NCCS, Pune). The cells were maintained as monolayers in Dulbecco's Modified Eagle's Medium (DMEM) with $2.0 \mathrm{mM}$ L-glutamine adjusted to contain $3.7 \mathrm{~g} / \mathrm{L}$ sodium bicarbonate, $4.5 \mathrm{~g} / \mathrm{L}$ glucose. Media was supplemented with $1 \%$ Penicillin (100 units/mL)-Streptomycin $(10,000 \mu \mathrm{g} / \mathrm{mL})$ and $10 \%$ fetal bovine serum. Cells were cultured in $25 \mathrm{~cm} 2$ tissue-culture treated flasks at $37 \mathrm{o} \mathrm{C}$ and $5 \% \mathrm{CO} 2$ in humidified chambers.

\section{Oxalate-induced Cell Injury}

NRK 52E cells were incubated in DMEM containing $1 \mathrm{mM}$ sodium oxalate in the presence of different concentrations of the aqueous extract of the test sample $(10 \mu \mathrm{g} / \mathrm{mL}, 25 \mu \mathrm{g} / \mathrm{mL}$ and $50 \mu \mathrm{g} / \mathrm{mL})$ for 72 hours $(14,17)$. Cell injury was assessed by measuring the cell viability through trypan blue and monitoring the lactate dehydrogenase (LDH) leakage into the medium.

\section{Cytotoxicity - Trypan Blue Assay}

The cytotoxicity of the aqueous extract of $\mathrm{T}$. terrestris was assessed by cell viability using trypan blue exclusion method. For the determination of cell viability, cells were plated at the density of $4 \times$ 104 cells/well and cultured for $72 \mathrm{~h}$. The medium was replaced with serum-free medium and the cells were treated with various concentrations of the plant extracts $(10 \mu \mathrm{g} / \mathrm{mL}, 25 \mu \mathrm{g} / \mathrm{mL}$ and $50 \mu \mathrm{g} / \mathrm{mL})$ for a further $72 \mathrm{~h}$. The percentage viability for the cells was calculated as (live cells/total cells) x 100 .

\section{LDH Leakage Assay}

LDH leakage assay was performed by the method described by Wagner et al. (18). Briefly, 6.6 $\mathrm{mM}$ NADH and $30 \mathrm{mM}$ sodium pyruvate were prepared in Tris (0.2M, pH 7.3). Reaction was initiated with the addition of $50 \mu \mathrm{L}$ of the test sample and the disappearance of NADH was monitored at $340 \mathrm{~nm}$, for $5 \mathrm{~min}$ at an interval of $1 \mathrm{~min}$. The percentage of LDH release was calculated by dividing the activity of LDH in the supernatant by the LDH activity measured after complete cell lysis achieved by sonication.

\section{Statistical Analysis}

Data were expressed as mean values of three independent experiments (each in triplicate) and ana- 
lyzed by the analysis of variance $(p<0.05)$ to estimate the differences between values of extracts tested.

\section{RESULTS}

\section{Inhibition of Nucleation of $\mathrm{CaOx}$ Crystals by Tribulus terrestris Extract}

Figure-1 displays the effect of the different concentration of the aqueous extract of Tribulus terrestris on the nucleation of calcium oxalate crystals. As regards control (with no plant sample), the percentage inhibition was constant at $71.4 \pm 0.001$ with increase in the concentration of Tribulus terrestris extract of 25 $\mu \mathrm{g} / \mathrm{mL}, 50 \mu \mathrm{g} / \mathrm{mL}$ and $100 \mu \mathrm{g} / \mathrm{mL}$. As the concentration of Tribulus terrestris extract was increased to 200 $\mu \mathrm{g} / \mathrm{mL}$, the percentage inhibition increased to $100 \pm$ 0.001 but was reduced to $85.7 \pm 0.002$ for $400 \mu \mathrm{g} / \mathrm{mL}$. The percentage inhibition was restored to $100 \pm 0.001$ with $1000 \mu \mathrm{g} / \mathrm{mL}$ of the extract.

\section{Inhibition of CaOx Crystal Growth by Tribulus terrestris Extract}

Figure-2 demonstrates the percentage inhibition shown by Tribulus terrestris on the calcium oxa- late crystal growth. Tribulus terrestris extract showed inhibition in a concentration dependent manner. The percentage inhibition with $25 \mu \mathrm{g} / \mathrm{mL}$ of plant sample was $17.6 \pm 0.004$. With $50 \mu \mathrm{g} / \mathrm{mL}, 100 \mu \mathrm{g} / \mathrm{mL}$ and 200 $\mu \mathrm{g} / \mathrm{mL}$, the inhibition was almost constant in the range of $65-70 \%$ but inhibition increased significantly with $400 \mu \mathrm{g} / \mathrm{mL}$ and $1000 \mu \mathrm{g} / \mathrm{mL}$ of Tribulus terrestris extract to $126.4 \pm 0.001$ and $169.2 \pm 0.001$ respectively.

\section{Diminution of Oxalate-induced Renal Tubular Epithelial Cell Injury by Tribulus terrestris Extract}

Figure-3 depicts the protective effect of the aqueous extract of Tribulus terrestris towards the renal tubular epithelial cells. The oxalate induced a significant injury to the cells which could be ascertained by a decrease in viability from $100 \%$ in the controls (untreated cells) to $73.9 \%$. However, the injury due to oxalate was significantly reduced in those cells treated with the Tribulus terrestris extracts. As the concentration of the extract increased from $10 \mu \mathrm{g} / \mathrm{mL}$ to $50 \mu \mathrm{g} / \mathrm{mL}$, the percentage viability improved showing that the plant has an inhibitory activity towards the oxalate which caused injury to the renal cells in a concentration dependent manner. The plant extract alone $(50 \mu \mathrm{g} / \mathrm{mL}$, containing $0.4 \%$ DMSO) had no

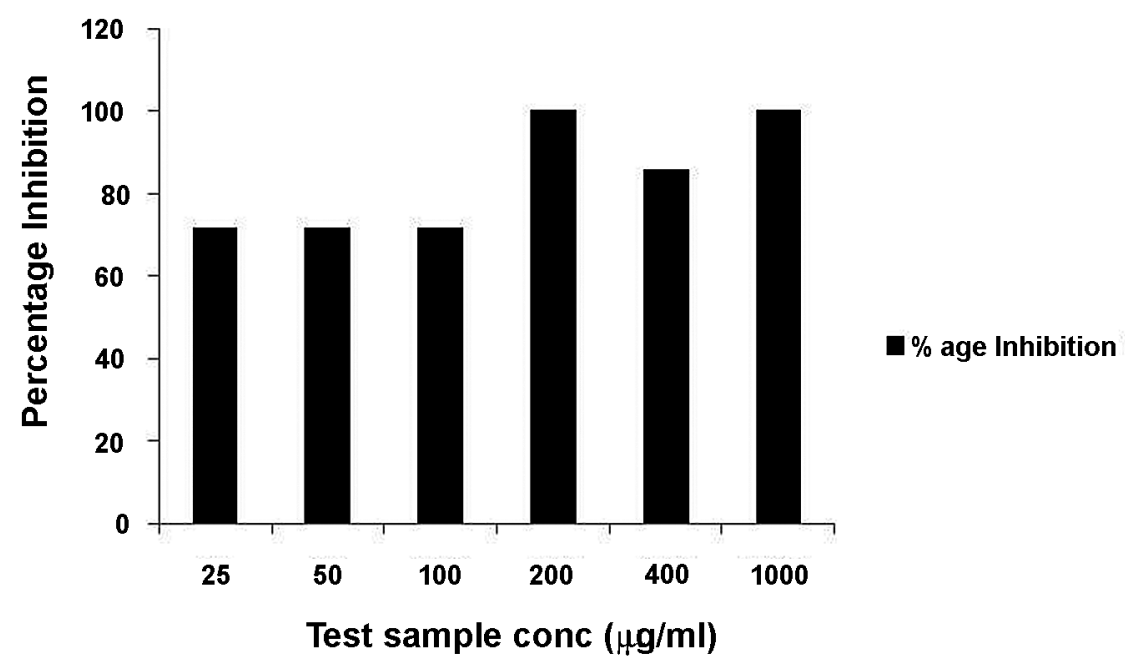

Figure 1 - Effect of Tribulus terrestris on nucleation of CaOx. 


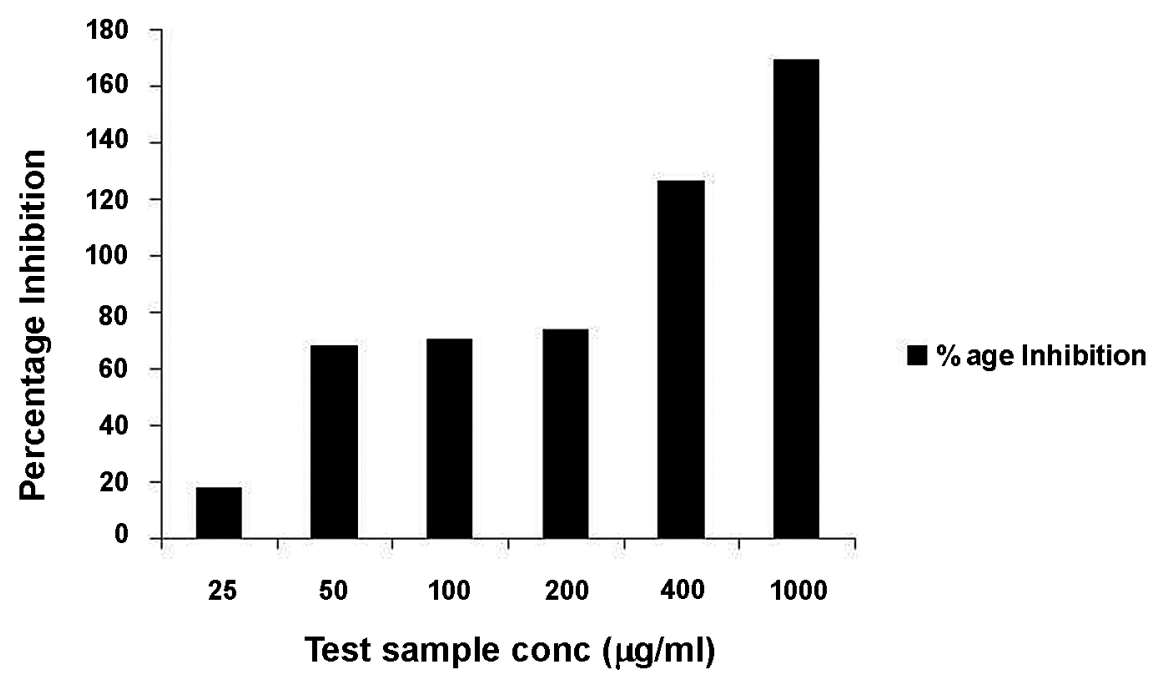

Figure 2 - Effect of Tribulus terrestris on the growth of $\mathrm{CaOx}$.

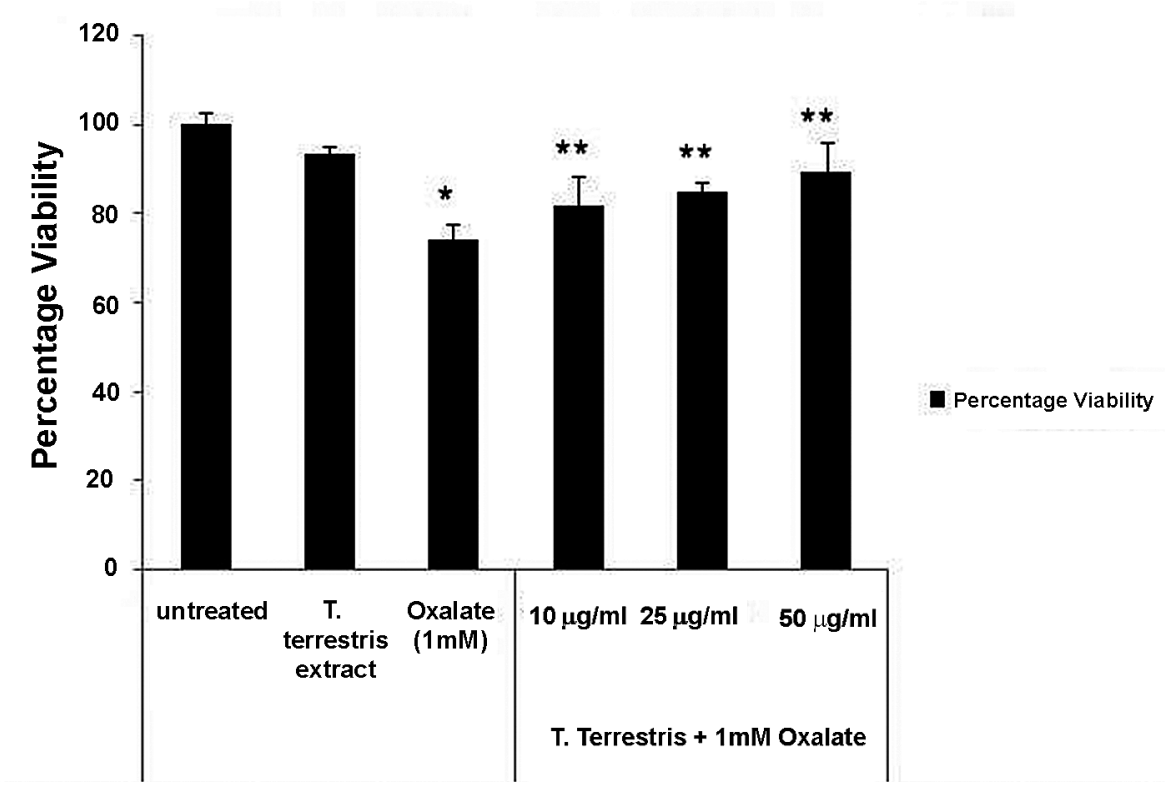

Figure 3 - Effect of Tribulus terrestris on the viability of NRK 52E. Data are mean \pm SEM of three independent observations. ${ }^{*} p<0.05$ versus untreated control, $* * p<0.05$ versus oxalate control.

effect on the cell injury in the absence of oxalate indicating that even at the highest concentration of DMSO used there was no cytotoxicity to the cells. The percentage viability with $10 \mu \mathrm{g} / \mathrm{mL}, 25 \mu \mathrm{g} / \mathrm{mL}$ and $50 \mu \mathrm{g} / \mathrm{mL}$ was $81.6 \pm 6.9,84.9 \pm 1.9$ and $89.1 \pm$ 6.9 respectively.
Lactate dehydrogenase is a stable cytosolic enzyme that is released when the cell is lysed or there is any injury on the cell membrane. A significant increase in LDH release was seen when the NRK 52E cells were exposed to oxalate alone. When NRK 52E cells were treated with the plant extract at varying 
concentrations $(10,25$ and $50 \mu \mathrm{g} / \mathrm{mL})$ along with oxalate $(1 \mathrm{mM})$ for $72 \mathrm{~h}$, a reduction in oxalate-induced cell injury was observed as assessed by a decreased LDH release (Figure-4), Again it was seen that the plant extract alone had no significant effect on the measures of cell injury in the absence of oxalate. The percentage LDH release for $10 \mu \mathrm{g} / \mathrm{mL}, 25 \mu \mathrm{g} / \mathrm{mL}$ and $50 \mu \mathrm{g} / \mathrm{mL}$ was observed to be $126.5 \pm 4.2,112.6 \pm$ 5.2 and $109.8 \pm 1.0$ respectively after treatment with oxalate and the plant extract with respect to control.

\section{COMMENTS}

There is growing evidence that $\mathrm{CaOx}$ nephrolithiasis is associated with renal injury. Hyperoxaluria is a major risk factor for calcium oxalate nephrolithiasis, and calcium oxalate urinary stones are the most common type of urinary stone. High level of oxalate produced a variety of changes in the renal epithelial cells, such as an increase in free radical production and a decrease in antioxidant status, followed by cell injury and cell death. These changes are significant predisposing factors for the facilitation of crystal adherence and retention $(5,14)$.
Due to significant side effects and failure to prevent recurrence by the present day treatment procedures for urolithiasis, alternative treatment modalities using herbal products have assumed importance. A dramatic advancement in using phytotherapy for urolithiasis treatments has been observed in recent years and many investigators have proposed to further scientific study on its efficacy. Many medicinal plants have been employed for centuries to treat urinary stones though the rationale behind their use is not well established.

In the present study, the anticalcifying properties of Tribulus terrestris commonly called "gokhru" were explored in vitro. The inhibitory potency of the plant was tested on the nucleation and growth of the most commonly occurring kidney stones, calcium oxalate monohydrate. A concentration dependent trend of inhibition was observed using Tribulus terrestris extract with maximum inhibition of $100 \%$ and $170 \%$ for $\mathrm{CaOx}$ nucleation and the growth assay respectively with $1000 \mu \mathrm{g} / \mathrm{mL}$ of the extract.

In our study with NRK 52E, Tribulus terrestris proved to have a protective effect towards the renal epithelial cells again in a concentration dependent manner. When NRK-52E cells were injured

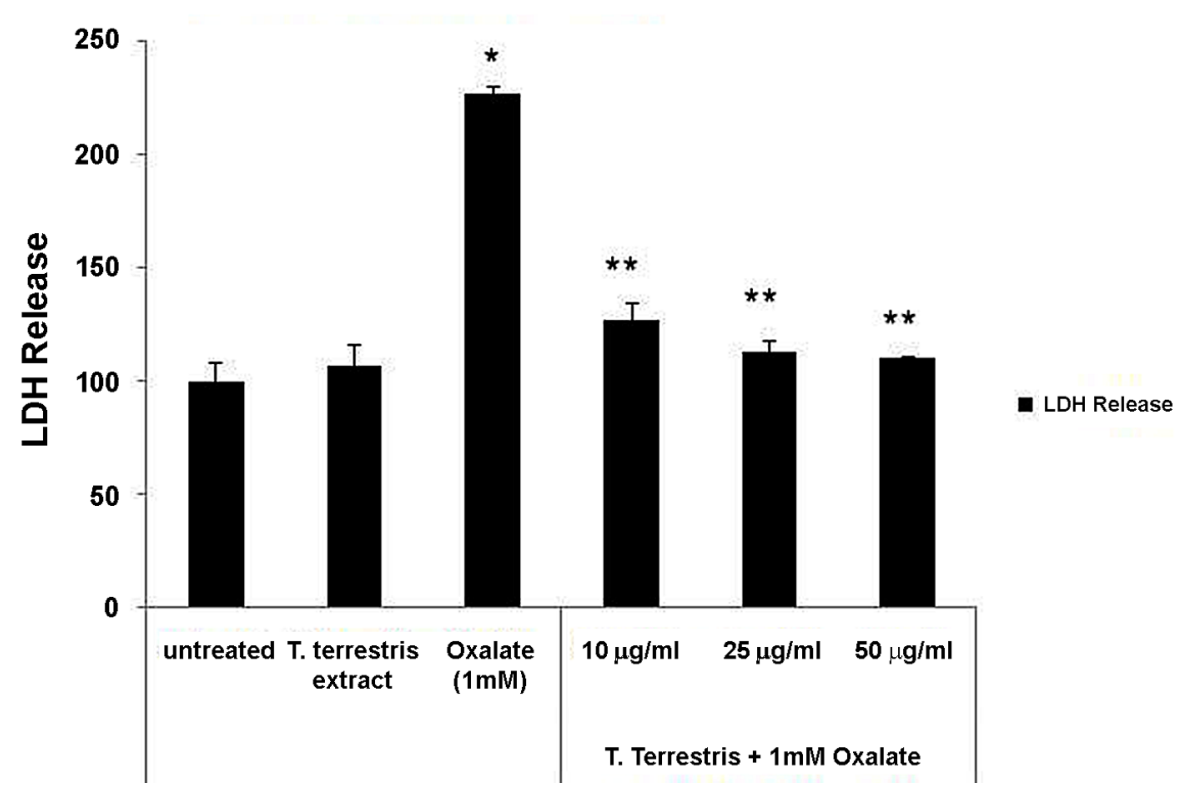

Figure 4 - Effect of Tribulus terrestris on the \% LDH release. Data are mean \pm SEM of three independent observations.

$* p<0.05$ versus untreated control, $* * p<0.05$ versus oxalate control. 
by exposure to oxalate for $72 \mathrm{~h}$, the plant extract prevented the injury in a dose-dependent manner. The mechanism of inhibition/reduction in the injury needs to be studied further. Studies have shown that inhibition of the inflammatory response induced by injury due to crystal formation helps in restoring normalcy.

Beghalia et al. (19) have suggested in studies using certain Algerian medicinal plants that the herb extract may contain substances that inhibit the growth of COM crystals. This property of plant extracts could be important in preventing kidney stone formation; the agglomeration of particles is a critical step in urinary stone formation, as larger crystals are less likely to pass spontaneously in the urinary tract $(8,20)$. They $(19)$ further postulated that the plant extracts may contain substances that inhibit $\mathrm{CaOx}$ crystal aggregation and also the binding of the crystals to the renal epithelial surface. This could explain a decrease in LDH release as seen in the cells treated with the plant extract compared to those treated with oxalate alone.

Our studies are in agreement with the studies previously reported as regards the anti-urolithiatic potency of Tribulus terrestris on the growth COM crystals using double diffusion gel growth technique (21). The anti-urolithiatic ability of the plant is also currently being evaluated in animal models and has exhibited dose-dependent anti-urolithiatic activity and almost completely inhibited stone formation further supporting our results $(22,23)$.

Recently several plants including Herniaria hirsuta (24), Phyllanthus niruri (25) and Bergenia linguata (26) are being explored for their anti-urolithiatic properties on the basis of their usage in the traditional medicine. Herniaria hirsuta, a plant from Morocco is also known to exhibit the antilithiatic activity. The adhesion of the radioactive COM crystals to the Madin Darby canine kidney cells was studied in the presence and the absence of the aqueous extract. COM crystal binding to the cells was inhibited by the extract in a concentration dependent manner (24). In vitro effect of an aqueous extract of Phyllanthus niruri L., a plant used in Brazilian folk medicine for the treatment of urolithiasis, on a model of $\mathrm{CaOx}$ crystal endocytosis by Madin-Darby canine kidney cells was investigated by Campos and
Schor. The extract exhibited a potent and effective non-concentration-dependent inhibitory effect on the $\mathrm{CaOx}$ crystal internalization. This response was present even at very high (pathologic) $\mathrm{CaOx}$ concentrations and no Phyllanthus niruri L.-induced toxic effect could be detected (25). Bergenia ligulata is a widely used plant in South Asia, mainly India and Pakistan, as a traditional medicine for treatment of urolithiasis. The crude aqueous-methanolic extract of Bergenia ligulata rhizome was studied using in vitro and in vivo methods and the extract showed the antiurolithic activity through $\mathrm{CaOx}$ crystal inhibition, diuretic, hypermagneseuric and antioxidant effects (26). Also in our laboratory, antilithiatic potency of Dolichos biflorus (27) and Trachyspermum ammi (28) has been evaluated in vitro and in vivo. The most active protein fraction was isolated from these plants and thus adds a new perspective to study plant fractions for their therapeutic use as antilithiatic proteins.

\section{CONCLUSION}

In conclusion, the aqueous extract of Tribulus terrestris has been shown to possess an ability to inhibit $\mathrm{CaOx}$ crystallization in vitro. In addition this extract has also shown cytoprotective properties towards the NRK 52E cells by lowering LDH leakage and increasing the cell viability. Our study suggests the possibility of using Tribulus terrestris as a therapeutic agent to treat urolithiasis and further characterization of its active compound(s) could lead to a new candidate drug for patients with urolithiasis.

\section{ACKNOWLEDGEMENT}

The Department of Biotechnology, Government of India, provided funds for this research work.

\section{CONFLICT OF INTEREST}

None declared. 


\section{REFERENCES}

1. Kumar V, Farell G, Deganello S, Lieske JC: Annexin II is present on renal epithelial cells and binds calcium oxalate monohydrate crystals. J Am Soc Nephrol. 2003; 14: 289-97.

2. Prasad KVSRG, Sujatha D, Bharathi K: Herbal Drugs in Urolithiasis - A Review. Phycog Rev. 2007; 1: 1759.

3. Verkoelen CF, Romijn JC, de Bruijn WC, Boevé ER, Cao LC, Schröder FH: Association of calcium oxalate monohydrate crystals with MDCK cells. Kidney Int. 1995; 48: 129-38.

4. Verkoelen CF, Verhulst A: Proposed mechanisms in renal tubular crystal retention. Kidney Int. 2007; 72: 13-8.

5. Khan SR: Calcium oxalate crystal interaction with renal tubular epithelium, mechanism of crystal adhesion and its impact on stone development. Urol Res. 1995; 23: 71-9.

6. Maroni PD, Koul S, Chandhoke PS, Meacham RB, Koul HK: Oxalate toxicity in cultured mouse inner medullary collecting duct cells. J Urol. 2005; 174: 757-60.

7. Jonassen JA, Kohjimoto Y, Scheid CR, Schmidt M: Oxalate toxicity in renal cells. Urol Res. 2005; 33: 329-39.

8. Kok DJ, Khan SR: Calcium oxalate nephrolithiasis, a free or fixed particle disease. Kidney Int. 1994; 46: 847-54.

9. Jethi RK, Duggal B, Sahota RS, Gupta M, Sofat IB: Effect of the aqueous extract of an Ayurvedic compound preparation on mineralization \& demineralization reactions. Indian J Med Res. 1983; 78: 422-5.

10. Barros ME, Schor N, Boim MA: Effects of an aqueous extract from Phyllantus niruri on calcium oxalate crystallization in vitro. Urol Res. 2003; 30: 374-9.

11. Kieley S, Dwivedi R, Monga M: Ayurvedic medicine and renal calculi. J Endourol. 2008; 22: 1613-6.

12. Miyaoka R, Monga M: Use of traditional Chinese medicine in the management of urinary stone disease. Int Braz J Urol. 2009; 35: 396-405.

13. Kandil O, Radwan NM, Hassan AB, Amer AM, el-Banna HA, Amer WM: Extracts and fractions of Thymus capitatus exhibit antimicrobial activities. J Ethnopharmacol. 1994; 44: 19-24.

14. Moriyama MT, Miyazawa K, Noda K, Oka M, Tanaka M, Suzuki K: Reduction in oxalate-induced renal tubular epithelial cell injury by an extract from Quercus salicina Blume/Quercus stenophylla Makino. Urol Res. 2007; 35: 295-300.
15. Hennequin C, Lalanne V, Daudon M, Lacour B, Drueke T: A new approach to studying inhibitors of calcium oxalate crystal growth. Urol Res. 1993; 21: 101-8.

16. Nakagawa Y, Abram V, Parks JH, Lau HS, Kawooya JK, Coe FL: Urine glycoprotein crystal growth inhibitors. Evidence for a molecular abnormality in calcium oxalate nephrolithiasis. J Clin Invest. 1985; 76: 145562.

17. Jeong BC, Kwak C, Cho KS, Kim BS, Hong SK, Kim JI, et al.: Apoptosis induced by oxalate in human renal tubular epithelial HK-2 cells. Urol Res. 2005; 33: 8792.

18. Wagner A, Marc A, Engasser JM, Einsele A: The use of lactate dehydrogenase (LDH) release kinetics for the evaluation of death and growth of mammalian cells in perfusion reactors. Biotechnol Bioeng. 1992; 39: 320-6.

19. Beghalia M, Ghalem S, Allali H, Belouatek A, Marouf A: Inhibition of calcium oxalate monohydrate crystal growth using Algerian medicinal plants. J Med Plants Res. 2008; 2: 66-70.

20. Wesson JA, Worcester EM, Wiessner JH, Mandel NS, Kleinman JG: Control of calcium oxalate crystal structure and cell adherence by urinary macromolecules. Kidney Int. 1998; 53: 952-7.

21. Joshi VS, Parekh BB, Joshi MJ, Vaidya AB: Herbal extracts of Tribulus terrestris and Bergenia ligulata inhibit growth of calcium oxalate monohydrate crystals in vitro. J Crystal Growth. 2005; 275: e1403-8.

22. Anand R, Patnaik GK, Srivastava S, Kulshreshtha DK, Dhawan BN: Evaluation of antiurolithiatic activity of Tribulus terrestris. Int J Pharmacog. 1994; 32: 217 24.

23. Anand R, Patnaik GK, Kulshreshtha DK, Dhawan BN: Activity of certain fractions of Tribulus terrestris fruits against experimentally induced urolithiasis in rats. Indian J Exp Biol. 1994; 32: 548-52.

24. Atmani F, Farell G, Lieske JC: Extract from Herniaria hirsuta coats calcium oxalate monohydrate crystals and blocks their adhesion to renal epithelial cells. J Urol. 2004; 172: 1510-4.

25. Campos AH, Schor N: Phyllanthus niruri inhibits calcium oxalate endocytosis by renal tubular cells: its role in urolithiasis. Nephron. 1999; 81: 393-7.

26. Bashir S, Gilani AH: Antiurolithic effect of Bergenia ligulata rhizome: an explanation of the underlying mechanisms. J Ethnopharmacol. 2009; 122: 106-16.

27. Bijarnia RK, Kaur T, Singla SK, Tandon C: A novel calcium oxalate crystal growth inhibitory protein from the seeds of Dolichos biflorus (L.). Protein J. 2009; 28: 161-8. 
28. Kaur T, Bijarnia RK, Singla SK, Tandon C: Purification and characterization of an anticalcifying protein from the seeds of Trachyspermum ammi (L.). Protein Pept Lett. 2009; 16: 173-81.
Accepted after revision: October 29, 2009

\section{Correspondence address:}

Dr. C. Tandon

Biotechnology and Bioinformatics

Jaypee University of Information Technology

Waknaghat, 173215, Solan, India

E-mail: tandonchanderdeep@yahoo.com

\section{EDITORIAL COMMENT}

Kidney stone disease is a major health problem in modern societies. As technology evolved, surgical options have gained more acceptance as they provide less invasive approaches, more efficacious results and lesser collateral effects. However, the costs involved are significant and an increasing effort should be continuously made in order to optimize prevention. The article presented by Aggarwal et al. clarifies the efficacy of the herbal Tribulus terrestris on the inhibition of calcium oxalate calculi formation. Herbal medicine has been long used to treat different health conditions including stone dis- ease. However, only more recently efforts began to be made to determine the mechanisms involved and their objective efficacy. In the present evidencebased medicine era this is of utter importance. Herbal medicines may be an alternative to the currently existing medicines providing the additional advantage of minimal or inexistent collateral effects. Other herbal medicines should undergo evaluations in vitro to amplify the urologist's clinical armamentarium to combat kidney stones.

Dr. Ricardo Miyaoka Department of Urologic Surgery University of Minnesota Minneapolis, MN, USA E-mail:miyao002@umn.edu 


\section{EDITORIAL COMMENT}

In this paper, the authors addressed the potential use of Tribulus terrestris as the therapeutic agent to treat urolithiasis. Urolithiasis is characterized by high recurrence rate and among the treatments used are extracorporeal shock wave lithotripsy and drug treatment, although there is no satisfactory drug to use in clinical therapy. Thus the prevention of this disease or its recurrence would be of great interest. Phytotherapy is a common method used in folk medicine as an alternative for primary health care in many countries and particularly the potential effect of many plants to treat urolithiasis has been reported over the past years. The precipitation of calcium oxalate $(\mathrm{CaOx})$ inside the renal tubules and the interaction between $\mathrm{CaOx}$ crystals and tubular epithelium plays an important role in the genesis and evolution of urolithiasis, since renal tubular cells selectively bind and uptake $\mathrm{CaOx}$ crystals, a phenomenon followed by a series of intracellular events that culminate in a cell damage and death. It was shown that aqueous extract of Tribulus terrestris was able to inhibit $\mathrm{CaOx}$ crystallization in vitro and showed cytoprotective properties increasing the cell viability.

The extract of plants with antilithiatic properties (Tribulus terrestris, Phyllanthus niruri, Herniaria hirsute, etc.) has been shown effective to prevent calculi development in the experimental models in vivo and in vitro, showing significant ef- fects on many stages of stone formation including crystallization, aggregation, cellular adherence and adsorption of macromolecules into the calculi, however, its effects in lithiatic patients are much less clear. Many reasons can be raised for this difference such as the treatment onset, number of patients, time of treatment, adhesion to the treatment, etc. Moreover, it was previously shown (1) that rats with already formed vesical calculi, the administration of Phyllanthus niruri had no effect on the calculi size or elimination rate but it induced a shift in the calculi shape toward a smoother surface and probably more fragile form, which could contribute to elimination and/or dissolution of calculi. Overall the available data point to a useful therapeutic application of these plants, including Tribulus terrestris in lithiatic patients, mainly as prophylactic agent in those persons who are at high risk to develop stones since they can potentially interfere with the pathogenesis of urolithiasis and may represent an attractive alternative for the prevention of lithiasis of the urinary tract.

\section{REFERENCE}

1. Barros ME, Lima R, Mercuri LP, Matos JR, Schor N, Boim MA: Effect of extract of Phyllanthus niruri on crystal deposition in experimental urolithiasis. Urol Res. 2006; 34: 351-7.

Dr. Mirian A. Boim Associate Researcher, Renal Division Federal University of São Paulo

São Paulo, SP, Brazil E-mail:mirian@nefro.epm.br 